\title{
Analysis of the Decline in Interest Towards School Science and Technology from Grades 5 Through 11
}

\author{
Patrice Potvin - Abdelkrim Hasni
}

Published online: 31 August 2014

(c) The Author(s) 2014. This article is published with open access at Springerlink.com

\begin{abstract}
Interest in school science and technology (S\&T) remains an important issue as it is linked to achievement and the intention to pursue studies or careers in S\&T. Around the world, a number of studies have shown that interest in S\&T declines with school years. However, some divergences from the general trend have been demonstrated in certain contexts, sub-periods, or for closely related subconstructs. We administered 2,628 questionnaires to students in grades 5 through 11 in the province of Québec, Canada. The questionnaire explored many factors (including out-of-school and school-related preferences, difficulty, importance, frequency), allowing us to track these closely related variables for a seven-year period. Among others, the results show a general degradation inschool S\&T factors but an improvement in out-of-school S\&T variables and of interest in S\&T studies and careers. S\&T is perceived as increasingly difficult and valuable compared with all other subject matters taken one-on-one. Some shorter fluctuations are analysed and interpreted in comparison with the evolution of certain teaching practices.
\end{abstract}

Keywords Science and technology - Decline - Interest towards School Science and Technology, Elementary/ Secondary School

P. Potvin $(\bowtie)$

Département de didactique, Université du Québec à Montréal, C.P. 8888, Succursale Centre-Ville, Montréal, QC H3C 3P8, Canada

e-mail: potvin.patrice@uqam.ca

\section{A. Hasni}

Faculté d'éducation, Université de Sherbrooke, 2500 boul. de l'Université, Sherbrooke, QC J1K 2R1, Canada

\section{Context}

Interest (and Other Neighbouring Concepts) Towards School Science and Technology

Cultivating positive attitudes, motivation, and interest in school tasks and scientific subject matters is not a futile issue. Even though it is sometimes understood as a desirable but inconsequential effect of successful teaching, recent research has argued that it might be more central to learning than believed ${ }^{1}$ :

From childhood through adolescence, across varied populations, those with higher academic intrinsic motivation are more competent in school, evidencing significantly greater academic achievement, more positive perceptions of their academic competency, lower academic anxiety, and less extrinsic motivation. (Gottfried et al. 2009, p. 729)

The study of the total effects revealed the important influences of academic time, attitude, and motivation on achievement. Of primary importance is the evidence of the strong effects of motivation, positive attitude, and engagement in academic work for success in mathematics and science (Singh et al. 2002, p. 330).

According to Pan, it has been well established that motivation is key to predicting students' academic achievement and research has shown that, "compared with aptitude (e.g., ACT/SAT scores, and IQ), academic motivation is a better predictor of college students' learning success" (Pan and Gauvain 2012, p. 92). Other authors

$\overline{{ }^{1} \text { Italics added. }}$ 
have also showed that motivation appears to be crucial for achievement (Cavas 2011, p. 31). It has also been understood that attitude plays an important part in the intention to pursue science studies. "In previous work in the USA and Australia, attitudes towards science classes have been found to be the best predictors of students' intentions to enrol in science classes" (Reid and Skryabina 2002, p. 69).

We therefore believe that the evolution of individual "interests/motivation/attitudes" should be further examined.

Attitude, Motivation, Interest, Enjoyment, and Enthusiasm

Many constructs have been developed and used to assess and describe the relationship that students develop with school S\&T, the methods used and subjects taught. Based on an earlier literature review of 12 years of research in the field, AUTHORS have concluded that, the construct of attitude is the most commonly used, followed by interest, ${ }^{2}$ and finally motivation (2014). "Science enthusiasm" and "enjoyment" were also found, however, less frequently. These constructs all have in their definitions (and in the tools used to measure them) certain components that are exclusive to each. Motivation, for example, is strongly linked to the idea of a "goal," whether of intrinsic (preferably) or extrinsic origin, that orients behaviour. Most of the time, the definitions used are derived from Bandura's models (ibid., p.10). The proposed definitions of interest seem to be, for the most part, very attached to the "object of interest." The main references supporting the use of the interest construct were Krapp and Hidi's work, which insisted on the 'relationship between individuals and objects' (ibid., p.10). Finally, most articles declare adhesion to the classical construct of attitude, which usually consists of three components (cognitive, affective, and behavioural), and the idea of "positive or negative (like or dislike) inclinations toward an object", and thus referred directly to Koballa's definition as formulated in the mid1980s (ibid., p.10). It is nevertheless striking to see that many research articles (almost half) do not provide definitions for the constructs they use.

The measurements many articles provide are often obtained by the use of very similar and shared questionnaire items such as agreements with "I look forward to science lessons" (Murphyet al. 2006) or "Science is good for everybody" (Pell and Jarvis 2010). But the main constructs have also been oftentimes divided into very impressive numbers of subconstructs, among which some appear to be more frequent. Such subconstructs sometimes focus on science itself, including its perceived importance,

\footnotetext{
${ }^{2}$ It was also the one that had been increasingly used, recently.
}

trust, and the enthusiasm it triggers, or on science as it exists at home, at school, in particular activities and extraschool ones, or in subdisciplines, like chemistry, or even with small learning objects, as small as the chemical bond. They also often focus on the perceived difficulty, selfconcept, or the intention to pursue science or have a career in the field, and refer very often to their affective, cognitive and behavioural components. It therefore appears that interest, motivation and attitudes and all their subconstructs participate in some sort of an unfinished struggle to study the relationship between students and school S\&T as objectively as possible.

Of all the many available interesting distinctions and dimensions, and of all the conclusions provided by their separate analyses (and comparisons/correlations), there is however a major concern regarding the widely recognized and unsettlingly widespread general decline shown in the majority of the measures taken of these indicators as school years progress.

\section{A Very Well-Documented Decline With Age or School Years}

The decline of major constructs of interest, motivation and attitude with age has often been documented in the science education literature. In 2003, Osborne et al. (2003) published a very interesting synthesis in which they identified no less than nine important studies published between 1976 and 2001 that reported a decline in the attitudes of students' "from age 11 onwards" (p.1060). It was added that "these all show how children's interest and attitude to science declines from the point of entry to secondary school. More worrying, at least in the UK, is some evidence that children's attitudes towards school science are declining even in primary schools" (ibid.). A year later, Venturini (2004), in the french-speaking network of research, reached the same conclusion, citing seven studies: "Attitudes towards science degrades as students progressed through school."3 A few years later, Barmby et al. (2008) also established an inventory of their own (publications from 1975 to 2006) on the decline of attitudes and found 15 that reported a decline at the secondary level versus only one that recorded none, and four that reported a decline at the elementary level versus four that reported none. More recently, Gottfried et al. (2009), citing seven more recent studies, wrote: "Math and science are of particular concern because developmental decline in math and science motivation and attitudes has been a pervasive phenomenon across the literature." These reviews, although not encouraging, nevertheless give us a rather clear idea of the evolution of

\footnotetext{
${ }^{3}$ Free translation of "l'attitude envers les sciences se dégrade au fur et à mesure que les élèves progressent dans leur scolarité" (p. 10).
} 
Table 1 Research articles that report a decline in interest, motivation, attitude or enthusiasm in S\&T

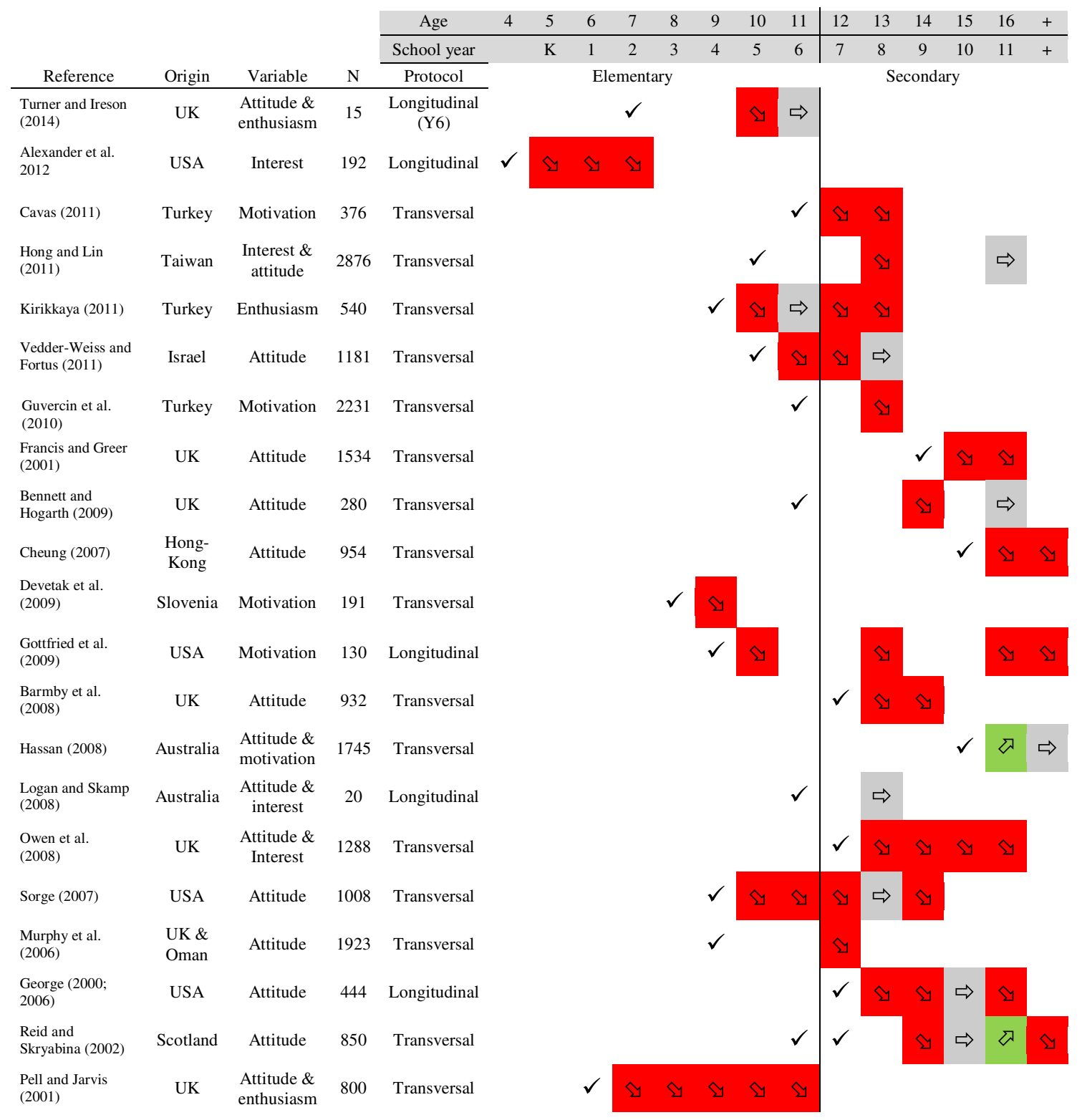

major constructs over the school years. To see if the tendency is still present, we conducted our own review of literature.

To be as synthetic as possible, we provide here the results from our own review of recent literature (since year 2000) in which we have found 21 ERIC-indexed articles about the decline of S\&T with age. Table 1 provides an overview of these studies, in the order of year of publication. The table includes the reference, origin of data, the studied variable, total number of participants, nature of the protocol [transversal (different students from different school years) or longitudinal (same students followed over long periods)], and considered school years for each study.
A checkmark indicates the lowest school year when measures were taken, a red arrow pointing down indicates a major or significant decline since the previously assessed level, a green arrow pointing up indicates an increase, and a grey arrow pointing sideways indicates that there was no major or significant variation. We included studies where the decline was the main focus, as well as studies where the decline was observed collaterally or, for example, during the validation of a new questionnaire. Arrows were used to represent, as faithfully as possible, what authors had themselves concluded for such variations. We have included constructs or subconstructs that were the closest to being about "school science," and not necessarily about 
science itself, or about school (or activities) taken independently. On a number of occasions, the authors of these articles presented other variations; they will be discussed later in this article.

This synthesized view allows us to see that declines have been widely recorded in many countries, with a considerably large number of participants and sometimes over rather long periods of time, even if these periods are sometimes shorter, have gaps, or are not as often studied with longitudinal designs, sometimes leaving much to be desired. Very few increases were observed regardless of the measured construct. When increases were recorded, authors sometimes associated them with punctual reductions of stakes with school year in certain states (Hassan 2008), or the effect of the chosen research protocol that might cultivate students' interest by making them think about the importance of school science (Logan and Skamp 2008), or special pedagogical treatments like Scotland's widely implemented and "highly popular [...] applications-led courses" (Reid and Skryabina 2002, p. 69).

The science education literature about interest, motivation, and attitude is indeed filled with declining (if not depressing) graphs or tables showing descents as school years increase. Based on such graphs and tables, many harsh conclusions have been formulated:

Tragically, it would appear that school has done nothing for them [students] in terms of stimulating their interest in science. In fact, [...] data show no improvement in attitude towards science from the age of 9 onwards, which leads to the speculation that, in some senses, school science education might do more harm than good! (Osborne et al. 2003)

This widespread situation has lead us to reflect on our local situation and to our first research question: (Q1) Will the students in the province of Quebec (Canada) demonstrate the same decline in interest towards school science and technology ( $\& \& T)$ with school years (or age) as reported elsewhere?

\section{Explanations That Literature Provides For The Decline}

To provide explanations to educators about the decline, various research initiatives have been conducted. For instance, complementary interviews lead by Barmby revealed that "school science is not perceived as practical [...]... as being well explained [or]... as relevant" (2008, pp. 1088-1089). Another example: in a very convincing longitudinal study that allows provision of causalities, George (2006) found that important time-varying predictors of both attitudes such as science self-concept, peer attitudes, teacher encouragement of science, and, to a lesser extent, student participation in science activities (p.571) could explain variations. Furthermore, "since the attitude scale was linked to the science classes taken by the students, it is possible to state that the decline in attitudes could be related to the type of science courses taken by students in each grade" (ibid., p.585).

But other non-school factors have also been invoked. For example, Güvercin, in 2010, proposed that "the findings may imply that as grade level increases, students become more concentrated on preparation for nation-wide examinations to get a good score. As a result, they are more likely to adopt more performance goal orientations while proceeding across grade levels." In this analysis, the declining interest could be simply attributed to the increase in stakes. Krapp (2011, p. 35) has also proposed possible explanatory approaches for the observed decline. "The first approach supposes that the development of science interest is primarily dependent on the quality and type of instruction." The above hypotheses by Osborne and George could be associated with this approach. "A second explanatory approach is based on findings and theories from the field of developmental psychology. It is postulated, for example, that students in adolescence tend to give priority to the coping with new developmental tasks and are no longer ready to invest all of their energy in academic learning" (ibid.). In this explanation, it would appear that school is understood as being unable to submit students to "developmental tasks," and would instead propose exclusively "academic" tasks, therefore appearing progressively more unsuitable, and thus more boring. "A third kind of explanation, the so-called differentiation hypothesis, assumes that the decline of the average science interest during adolescence stems primarily from the fact that young people, when searching for their own identity, subject their abilities and interests to a critical evaluation. All interests which do not seem to be compatible with the ideal selfconcept are devalued and excluded from the student's personally important interest pattern $[\ldots]$. From this perspective, the negative developmental trend in the student population is, thus, first and foremost an inevitable consequence of the normal differentiation of interest which occurs in adolescence" (ibid.). This explanation would render the observation of a decline somewhat inevitable, especially, we presume, when social pressure is exerted on students to choose a profession and give up other possibilities. We believe, however, that other, although not exclusive, explanatory approaches could be proposed. We know for example that, compared with young children, adolescents deploy more developed criticism competencies. Although not always constructive, this criticism would be difficult (and probably not advisable) to avoid and could explain at least some of the decline. Another explanation would attribute a role in the declining interest in "school science" to a mere decline in interest in 
"science" as a subject. As we can see, many proposed explanations are for the moment merely at the state of hypotheses. We believe it is important to keep on documenting the decline to bring new light on the topic. Unfortunately, available research initiatives are mostly limited to absolute measures of relations to school S\&T. Therefore, it is very difficult to see if the observed decline is attributable to the school $S \& T$ experience in particular or to the more general school experience. To tackle this difficulty, we were inspired by Osborne's (2003) suggestion that preference toward other disciplines rankings could be used.

Preference ranking is simple to use and the results of such research are easily presented and interpreted. Its fundamental problem is that it is a relative scale. Hence, it is possible for a student with an extremely positive attitude to all school subjects to still rank science as the least popular, and yet still have a much more favourable attitude than another student who has a strong dislike for all subjects and ranks science first [...]. However, this would suggest that it is an instrument not to be used in isolation rather than discarded totally. (p.1056)

However, since the object of our study is the evolution of interest, then the evolution of preference rankings with age can be analysed. This leads us to our second research question: (Q2) What is the evolution of preference rankings of $S \& T$ in comparison to other disciplines? Since "other research shows that attitudes to all subjects decline in general during adolescence" (Osborne et al. 2003, p. 1060), combining absolute measures to preferences might be explanatorily more robust.

\section{Recorded Divergences From The General Trend} and Interpretations They Lead To

Beyond the general rather depressing and apparent collapse, many research articles have argued that circumstances exist where the decline is uneven, incompletely explored or sometimes even reversed. The measures taken in some of these research studies lead us to believe that the decline is not entirely inevitable, nor completely understood.

The theoretical and practical relevance of such general developmental trends is often misjudged. They only provide information about changes in the average interest of a student population and cannot easily be used to describe or predict the most probable course of an individual's interest development in this domain. This is due to the fact that the trend analyses are based on aggregated data and thus do not provide an insight into the course of interest development in specific subpopulations or particular subject areas [...] which deviate from these data. In fact, more exact analyses of the data available from longitudinal studies show that, realistically, very different developmental curves must be expected and that it is not in any way justifiable to postulate a generally negative developmental trend in the domain of science interests. (Krapp and Prenzel 2011, p. 43)

The following sections present such divergences and the conclusions made by the researchers who observed them. They make additional research questions emerge.

\section{Subconstructs That Do Not Decline}

The findings from [...] differentiated analyses are striking in that they show that both the interest level and the course of interest development in science subjects depend strongly on the perceived attractiveness of the prevalent curriculum's lesson content ${ }^{4}$ on the one hand, and, on the other hand, on the manner in which scientific knowledge is presented and taught. Against the background of these results, strong doubts are cast on the validity of the statement that interest in science generally sinks dramatically at secondary level, which can be found frequently in scientific literature. (Krapp and Prenzel 2011, pp. 4344)

This very important invitation for differentiated analyses leads us to consider the results obtained by Barmby et al. (2008), in which, for grades 7 through 9, the construct "importance of science" did not decline yet "learning science in school" dropped considerably. The same can be said of George's analysis where items such as agreement to the statement "I enjoy my science class" declined with age while the "utility of science" component (obtained for example with agreements to "science is useful in everyday living") did not. For this author, since there is a rupture between these variables, it is clear "that the decline in attitudes could be related to the type of science courses taken by students in each grade" (George 2006, p. 585). Osborne also noticed that "a strong feature of the literature is the apparent contradiction between students' attitudes towards science in general and their attitudes towards school science. Many surveys show repeatedly that students' attitudes towards science itself are positive." (Osborne et al. 2003, p. 1061) He also notes that "even $71 \%$ of those who had dropped science still rated it as

\footnotetext{
$\overline{{ }^{4} \text { Italics added. }}$
} 
interesting" (Osborne et al. 2003, p. 1061) and appears to agree with other authors in "that science is somehow (perceived as) disconnected from society and that we should simply study it for its own sake" (ibid.).

This possible rupture between the relation students have with science and the one they have with school science can easily be tested, and put in relation with age, to explore this evolution. Indeed, many frequently used subconstructs of interest, motivation or attitude can relate to either school S\&T or merely to S\&T, as Barmby and George suggested in their work. Unfortunately, this difference has, for the moment, only been tested for short intervals of time. We propose to do it in our local context and on a larger time span. This leads us to our third research question: (Q3) Can the eventually recorded decline in interest towards school $S \& T$ be associated with the evolution with time of other frequently used subconstructs of interest that are associated with school $S \& T$ or to $S \& T$ alone?

\section{Boy-Girl Differences}

The difference between the declines in interest of girls vs. boys is not well understood. For very young students (aged 4-7), "results revealed significant time effects for boys [...] with proportion of contacts in which science was reported as an interest decreasing significantly over time [but] did not decline significantly for girls." (Alexander et al. 2012, p. 774). At the other extreme of the age spectrum, another study reported a comparable difference among near-university Chinese students with regard to chemistry (Cheung 2007). In other contexts, such as in UK, the opposite was also recorded: "pupils' attitudes towards science declined as they progressed through secondary school, and this decline was more pronounced for female pupils [...] this construct becomes a greater influence on attitudes towards future participation in science" (Barmby et al. 2008, p.1075). Another study in the UK among students in Years 9 through 11 found the same trend (Francis and Greer 2001). "Most articles that tackled the issue reported very slight or non-significant differences between general I/M/A for boys and girls toward science and technology $[\ldots]$. When general differences were recorded, they were mostly at a slight advantage for boys and, with a few exceptions, recorded at the elementary level" (AUTHORS 2014, p.17).

Recorded differences are therefore usually rather small, and appear to be context-dependent. Even though the deepest differences between boys and girls were noted in subdisciplines or smaller-than-disciplines context or problems (ibid.), we will nevertheless investigate this matter. Therefore, our fourth research question becomes: (Q4) How does the decline in interest among girls compare with that among boys for our participants?
The Elementary/Secondary Transition and Other Short Transitions

Alexander et al. (2012) had already noticed that very young children (especially boys) transitioning into school and immediately thereafter tended to have a decline in interest. ${ }^{5}$ Other researchers have, respectively, noticed, arguing with data (Sorge 2007) or by an analysis of the literature (Venturini 2004), that "unmistakably a precipitous drop in science attitudes takes place between elementary school and middle school" and that "there is a greater decline in the move to middle school." ${ }^{\prime 6}$ Sorge $(2007$, p. 6 ) added that "further research on the relationship of the move from elementary school to middle school to changes in science attitudes is merited. It would be helpful to determine if maturation or cultural influences are factors in this change." We will respond to this general invitation by confirming that the elementary-secondary decline can also be observed in our local context: (Q5a) Will our participants show the same steeper decline during the elementarysecondary transition as reported elsewhere? This analysis will be conducted on other subconstructs as well (the same ones that were studied in Q3). While being there, we will also check if other important shorter variations happen during other transitions of the school path of local students.

Since it has been hypothesized that class interventions have an effect on the evolution of students' interest (Krapp's first explanatory approach), another exploration will be conducted in which we will investigate for variations from 1 year to the other in the frequency of use of different types of teaching practices that are typical of school S\&T. We will then propose some possible interpretations for eventual short variations. We will also provide regressions to explore the evolutions of the frequencies of teaching practices over the entire interval (grades 5-11) to provide pedagogical hypotheses for the general decline $(\mathrm{Q} 5 \mathrm{~b})$.

\footnotetext{
5 "Parents reported that boys' interests related to science declined significantly between the preschool years and early elementary school years, whereas girls' interests were reported to remain relatively low and stable. Although it is unclear why boys' interests tended to decline, parents frequently mentioned during our phone contacts that after first grade began, their child had considerably less free time in which to engage in play activities related to his interests. Many parents also reported that children became more sensitive to the particular interests of their peers and tended to align their play interests to activities preferred by same-sex peers, in particular." (Alexander et al. 2012, p.781).

${ }^{6}$ Free translation of "Une dégradation plus significative s'opère lors du passage dans le secondaire" (Venturini 2004, p.11).
} 
Contexts Where Academic Stakes or Perceived Difficulty Differ

Tony Pell and Tina Jarvis recorded that, for very young children (grades 1 and 2), the correlation coefficient given by "enthusiasm" and "difficulty" is positive and that pupils in these grades "are enthusiastic about science" while it is simultaneously "seen as difficult." This surprising result has been interpreted with the possibility that "negative views of difficulties are subsumed because of the novel experience." However, they add: "by [grade] 5, any lack of enthusiasm for science appears to be related to perceptions of difficulty." Indeed, after grade 5, divergences from the general trend of decline have been widely reported by many studies for contexts where performance stress is different. For example, Murphy et al. (2006, p. 417) recorded a greater decline in Ireland compared to Oman and attributed it to the presence of national testing. For Owen, the general decline observed in his participants could be attributed to the fact that the changes in subject matter were "perhaps becoming more complex, less intuitive and, in the case of physics, increasingly mathematical" (2008, p. 126).

To explain a sudden increase in motivation among his subjects, Hassan wrote: "As science is a compulsory subject for all [grade] 10 students in Australia, this might been one of the reasons that [grade] 10 students are less interested. Students may feel more motivated and find science more enjoyable when they are not under an obligation to study science" (Hassan 2008, p. 141).

Some authors also suggest that the decline that occurs when entering middle school could be explained by a shift "from a focus on participation to a focus on performance" and that "such a transition is difficult for many students" (Cavas 2011, p. 39). Based on their earlier research, Logan and Skamp (2008) indicated that "in the cross-sectional attitudinal survey it was found that when science is perceived to be more difficult, interest declines" (p.521) and that " $[\mathrm{t}]$ his correlation is supported, to an extent, in this study as all participant students whose science interest scores declined markedly over the transition had an increase in science difficulty sub scores. Sixty-one percent of participant students perceived secondary science to be more difficult than primary" (ibid.).

Explanations suggesting that performance stress has a negative impact on interest, can often be found in research literature. We will explore such possible links with our local participants. In line with our second research question, where we argued that comparisons with other disciplines can lead to more robust results, our sixth research question becomes: (Q6) What is the evolution of perceived importance and of perceived difficulty rankings of $S \& T$ in comparison to other disciplines?
We believe bringing elements of answers to these six questions will contribute to the debate, since this research has been conducted on an extended number of levels (5-11) with a considerable number of participants and with multiple relevant subconstructs (preference, science outside of school, difficulty, etc.). This will thus allow us to put the common phenomenon of the decline in interest into an original perspective. The research will also allow an analysis of the evolution of participants' interest as it has never before been analysed in such depth in our province.

\section{Methods}

Participants and Procedure

The participants were 1,451 french-speaking girls and 1,121 french-speaking boys [total $N=2,628$ usable questionnaires (with consent)] from school years (grades) 5 through 11 in 40 schools in the greater Montreal area and which belong to five of the biggest school boards in the province of Québec, Canada. These students were recruited with the help of the educative services directors from these school boards, their academic advisors, and the elementary and science teachers, under the instructions to identify "typical or representative" classes of students. The questionnaire was administered during class time with the permission of the teachers who were willing to make up for the lost teaching minutes in other teaching periods. Once the classes were identified, the teachers were instructed to show the students a short video (https://www.youtube.com/ watch? $\mathrm{v}=\mathrm{NE} 30-\mathrm{nD} 0 \mathrm{LrI}$ ) introducing the project, its objectives, and its importance. They were then instructed to read the instructions aloud and allow about $30 \mathrm{~min}$ (sometimes a little more was needed) to complete the questionnaire. The teachers were also instructed not to influence students if they needed clarification but not to refrain from helping them when asked.

\section{Measures}

We used the CRIJEST General Questionnaire, which is composed of 139 questions, 5 socio-contextual questions, 8 open-ended questions, and 126 Likert-style questions. Most of these questions had six response levels (an even number to avoid choosing the middle answer and constraining reflection), but some had only four, with very few offering "I do not know" as a choice. Most questions were about agreement ("Strongly disagree" $\rightarrow$ "Strongly agree"), while some were about preferences ("I prefer math" $\rightarrow$ "I prefer science"), frequency ("Never" $\rightarrow$ "Very often"), and a few about other pairs ("Hate" $\rightarrow$ "Like"; "Dissatisfied" "Strongly satisfied"; "X much more important" $\rightarrow$ 
"Y much more important"; etc.). This questionnaire was adapted and pre-experimented with 220 students to ensure that very young children could understand the questions as well as older ones and that $30 \mathrm{~min}$ would be sufficient time to complete the questionnaire. The statistical validity of important parts of the questionnaire was tested in a previous analysis (AUTHORS, submitted). Given the very large number of items, two versions of the questionnaire were created for the purpose of avoiding that taking the test might be too long and tiring. One was distributed to students whose names began with a letter between "A" and "J" (inclusively), and the other to the remaining participants. About two-thirds of the questions were identical in both versions, leaving the less critical items to be answered by only half the participants. This explains why some of our analyses were obtained with half the population. The questions, mostly inspired by classic questionnaires about attitude, motivation or interest (SMQ2, TOSRA, Pell \& Jarvis', etc.) were adapted to Québec's curriculum, where, for example, science education becomes "science and technology", physics and chemistry become "material world", and where the social sciences are identified as "social universe".

The questionnaire, administered in 2013, had four sections: "Me and my entourage" (socio-contextual; family and friends support, and self-concept questions); "S\&T in society" (utility; importance and relevancy); "S\&T at school" (portrait of school practices; preferences; importance vs. other disciplines; difficulty; general interest, etc.) and "S\&T careers" (attraction; sources of information; etc.). Items about affective, cognitive; behavioural (intentions of behaviour), and perceived importance components (which correspond to important components of attitude, interest or motivations) were included in each section.

For this study, we only analysed the part of Likert-style items that could provide answer elements related to our research questions.

A complete list of items used can be found in appendix 1 , in the format in which they were presented to the participants.

\section{Analyses}

Since we were interested to the general evolution of interest for the entire considered timespan, we conducted linear regressions (with the school year as the independent variable). This allowed us to obtain slopes and to see if these tendencies were significant. For the presentation of the data, we got inspired by some of the most convincing available research articles in the field (George 2006), and presented the general tendencies in classic and easy-to-read formats (graphs with $95 \%$ confidence intervals and tables with intercepts (at school year $=5$ ), slopes (positive and negative), and levels of significance).

For year-by-year analyses, we associated grade levels in pairs (e.g., Y5-Y6; Y6-Y7, etc.), conducted t tests, and calculated Cohen's $d$, $^{7}$ which gave the effect size within each pair, and allowed for the appreciation of shorter variations. This method of analysis reproduces formats used by some of the most reputed research (Barmby et al. 2008) done in the field. We hope that using these standardized formats will favour the possibility of comparisons and dialogue between studies and researchers.

The central factor of this study is "interest in school S\&T," which will average results from five selected items [101; 102; 103 (reversed); 104; and 105 (reversed) (Cronbach's $\alpha=0.89$ )]. Other selected factors include "importance of out-of-school S\&T," which averages results from five items [28 (reversed); 29; 30; 31; and 32 (Cronbach's $\alpha=0.76$ )]; "utility of out-of-school S\&T for society," which averages results from four items $[24 ; 25$; 26; and 27 (Cronbach's $\alpha=0.68$ )]; "utility of school S\&T for everyday life," which averages results from four items [109 (reversed); 110; 111; 112) (Cronbach's $\alpha=0.65)$ ] and "difficulty of school S\&T" which averages results from six items $[52 ; 63 ; 64 ; 65 ; 66$; and 67 (all reversed) (Cronbach's $\alpha=0.83$ )]; "School S\&T self-concept," which averages results from six items $[18 ; 19 ; 20 ; 21 ; 22$; and 23 (reversed) (Cronbach's $\alpha=0.82$ )]; and "attraction to S\&T studies and careers," which averages results from six items [130; 131 (reversed); 134; 135 (reversed); 136; and 137 (reversed) (Cronbach's $\alpha=0.91$ )].

In one case, comparative variables have been obtained by subtracting scores from two items. For example, the "perceived difficulty of X compared to school S\&T" (X being different school subjects, such as mathematics and English) would be obtained by calculating the difference between the expressed level of difficulty for "mathematics" (item 50) and the expressed level difficulty for "S\&T" (item 52). All other analyses were conducted on results for items taken alone and that were sometimes (items 50-55 and 63-67) reversed because they were negative.

\section{Ethics}

An ethics certificate ("Attestation de conformité") for this research procedure was obtained in January 2013 from the comité d'éthique de la recherche éducation et sciences sociales de l'Université de Sherbrooke.

\footnotetext{
7 Cohen's $d$ is defined as the difference between two means divided by a standard deviation for the data. Cohen (1969) categorizes effect sizes of $0.3,0.5$, and 0.7 standard deviations as "small," "medium," and "large".
} 
Table 2 Results of the linear regression analysis for general interest in school S\&T

\begin{tabular}{lllll}
\hline & $N$ & Intercept & Slope & $p$ \\
\hline Interest in school S\&T & 1,241 & 4.81 & -0.176 & $<0.001^{* *}$
\end{tabular}

$* p \leq 0.05 ; * * p \leq 0.005$

\section{Results}

All linear regressions presented in this section were conducted in relation to the school year. All intercepts presented in the tables are about grade 5 (earliest taken measures). Some t tests were added, generally outside the tables and figures to consolidate important observations. The number of participants $(N)$ varies from one test to the next because the contributing items were sometimes used in both versions of the questionnaire, and sometimes in only one. This explains why $N$ is sometimes close to the total number of subjects, and other times closer to half. Indicated " $p$ " values are about slopes. All intercepts, without exception, were significant $(p \leq 0.05)$.

Research Question No. 1: Will the Students in the Province of Quebec (Canada) Demonstrate the Same Decline in Interest Towards School Science and Technology (S\&T) with School Years (or Age) as Reported Elsewhere?

Table 2 shows the results of the linear regression analysis for General interest in school S\&T. Considering that the threshold between disagreement and agreement with the statements' items is 3.5 , interest is clearly positive at the elementary level and will remain positive until the end of the secondary level (intercept at $\mathrm{Y}-11$ is 3.754). Thus, students have a rather positive perception of school S\&T right through to the end of their schooling. The slope, however, is clearly negative and, in comparison with the evolution of other variables analysed in this article, it is not too harsh to say that it is rather abrupt. Therefore, like many other declines studied internationally, an "absolute" decline appears to also be reality for our Québec participants.

Research Question No. 2: What is the Evolution of Preference Rankings of S\&T in Comparison to Other Disciplines?

For this analysis, we will concentrate on slopes. Table 3 shows the regressions for Preference for other subjects over school S\&T. It is interesting to see that despite the decline in "general interest in school S\&T" (Table 2), many other subjects (and not the least important ones) such as French
Table 3 Results of the linear regression analysis for the preference for other subjects over school S\&T

\begin{tabular}{llllc}
\hline & $N$ & Intercept & Slope & $p$ \\
\hline Arts & 1,240 & 3.661 & 0.063 & $0.024^{*}$ \\
English (as a second & 1,246 & 2.984 & 0.054 & $0.039^{*}$ \\
$\quad$ language) & & & & \\
French (as a first language) & 1,243 & 3.157 & -0.062 & $0.012^{*}$ \\
Mathematics & 1,244 & 3.893 & -0.134 & $<0.001^{* *}$ \\
Physical education & 1,238 & 4.214 & -0.101 & $<0.001^{* *}$ \\
Social Universe & 1,245 & 2.902 & 0.07 & $0.005^{* *}$ \\
\hline
\end{tabular}

$* p \leq 0.05 ; * * p \leq 0.005$

(as a first language), mathematics, and physical education have negative slopes, suggesting that the decline in interest in these subjects could be even more pronounced than the general interest in school S\&T. It is also interesting to see that the other half of subjects have positive slopes. These two observations combined suggest that the decline in interest in school S\&T is not uncommon among subjects and that it is likely that declines in other subject matters could be recorded, some even more pronounced than S\&T.

Research Question No. 3: Can the Eventually Recorded Decline in Interest Towards School S\&T be Associated with the Evolution with Time of Other Frequently Used Subconstructs of Interest that are Associated with School S\&T or to S\&T Alone?

Table 4 gives regressions for different subconstructs of interest. First, these results seem to support the hypothesis of the independence of school S\&T and of the importance of out-of school S\&T. Indeed, keeping in mind the absolute decline in the general interest in school S\&T, both "out-ofschool" subconstructs have very high intercepts and positive slopes. This means that, while some important in-school subconstructs (School S\&T self-concept; difficulty of school S\&T) follow, and possibly explain, the general decline in interest in school S\&T, we see indications that the perceptions of S\&T itself resist this decline. This rupture might also be illustrated by the indecisiveness [intercept, very near the middle (3.5) value] and the absence of significant result for "utility of school S\&T for everyday life," despite the large number of participants. Second, the results also suggest that there might be a connection between the general decline, the perceived difficulty and the S\&T self-concept, even though these two started favourably (intercepts of 2.657 and 4.521, respectively). Third, it is a bit surprising that the "Attraction towards S\&T studies and careers" does not follow the General decline of interest for school S\&T. Instead, it significantly improves with schooling, suggesting that it survives the increasingly negative school experiences. 
Table 4 Results of linear regressions for considered subconstructs

\begin{tabular}{|c|c|c|c|c|}
\hline & $N$ & Intercept & Slope & $p$ \\
\hline $\begin{array}{l}\text { Importance of out-of school } \\
\text { S\&T }\end{array}$ & 1,223 & 4.027 & 0.032 & $0.039 *$ \\
\hline $\begin{array}{l}\text { Utility of out-of-school } \\
\text { S\&T for society }\end{array}$ & 1,203 & 4.244 & 0.106 & $<0.001 * *$ \\
\hline $\begin{array}{l}\text { Utility of school S\&T for } \\
\text { everyday life }\end{array}$ & 1,216 & 3.758 & -0.003 & 0.868 \\
\hline Difficulty of school S\&T & 939 & 2.657 & 0.046 & $0.017^{*}$ \\
\hline School S\&T self-concept & 2,493 & 4.521 & -0.031 & $0.002 * *$ \\
\hline $\begin{array}{l}\text { Attraction to } S \& T \text { studies } \\
\text { and careers }\end{array}$ & 2,381 & 3.768 & 0.043 & $0.005^{* *}$ \\
\hline
\end{tabular}

Table 5 Results of the linear regression analysis for general interest in school S\&T by gender

\begin{tabular}{lllll}
\hline & $N$ & Intercept & Slope & $p$ \\
\hline Boys & 559 & 4.867 & -0.145 & $<0.001^{* *}$ \\
Girls & 687 & 4.747 & -0.194 & $<0.001^{* *}$ \\
\hline
\end{tabular}

$* p \leq 0.05 ; * * p \leq 0.005$

Research Question No. 4: How Does the Decline in Interest Among Girls Compare with that Among Boys for Our Participants?

Table 5 provides the same results as Table 1, but with boys and girls separated. While both slopes remain clearly significant, there appears to be very little difference between boys and girls. Regardless of the school year $(t(1,226)=$
-4.040, $p=0.013$ ), the magnitude of the difference $(d=0.22)$ is small and in favour of boys. But the same differences at the beginning (grade 5) and the end (grade $11)$ of the period studied are non-significant $(t(137)=$ $-1.684, p=0.122 ; t(50)=-3.021, p=0.102$, respectively). The slimness of this difference might explain the lack of consensus about its existence. Still it can be said that the decline in girls is slightly steeper.

Research Question No. 5a: Will Our Participants Show the Same Steeper Decline During the ElementarySecondary Transition as Reported Elsewhere?

Table 6 shows the effect sizes of the transitions between school years for each subconstruct. Effect sizes that are higher than 0.3 and lower than -0.3 (higher than "small" according to Cohen) are indicated in bold.

It is interesting to note that the elementary/secondary (6-7) transition has a rather strong negative impact on some of our subconstructs. Significant differences were indeed easier to observe at this moment (including for General interest in school S\&T) and the negative effect sizes are greater at this moment than anywhere else, except in some insignificant cases for two late and isolated transitions for "utility of out-of-school S\&T for society" and "utility of school S\&T for everyday life," as well as for "attraction for S\&T studies and careers" for the last transition. Needless to say that "difficulty" also increases significantly during this transition, although not to the same degree.

Another major fluctuation occurs during the transition from grades 8 to 9 , at which time all subconstructs are positive (except, of course, "difficulty") and increase significantly,

Table 6 Effect sizes of transitions between school years for each factor

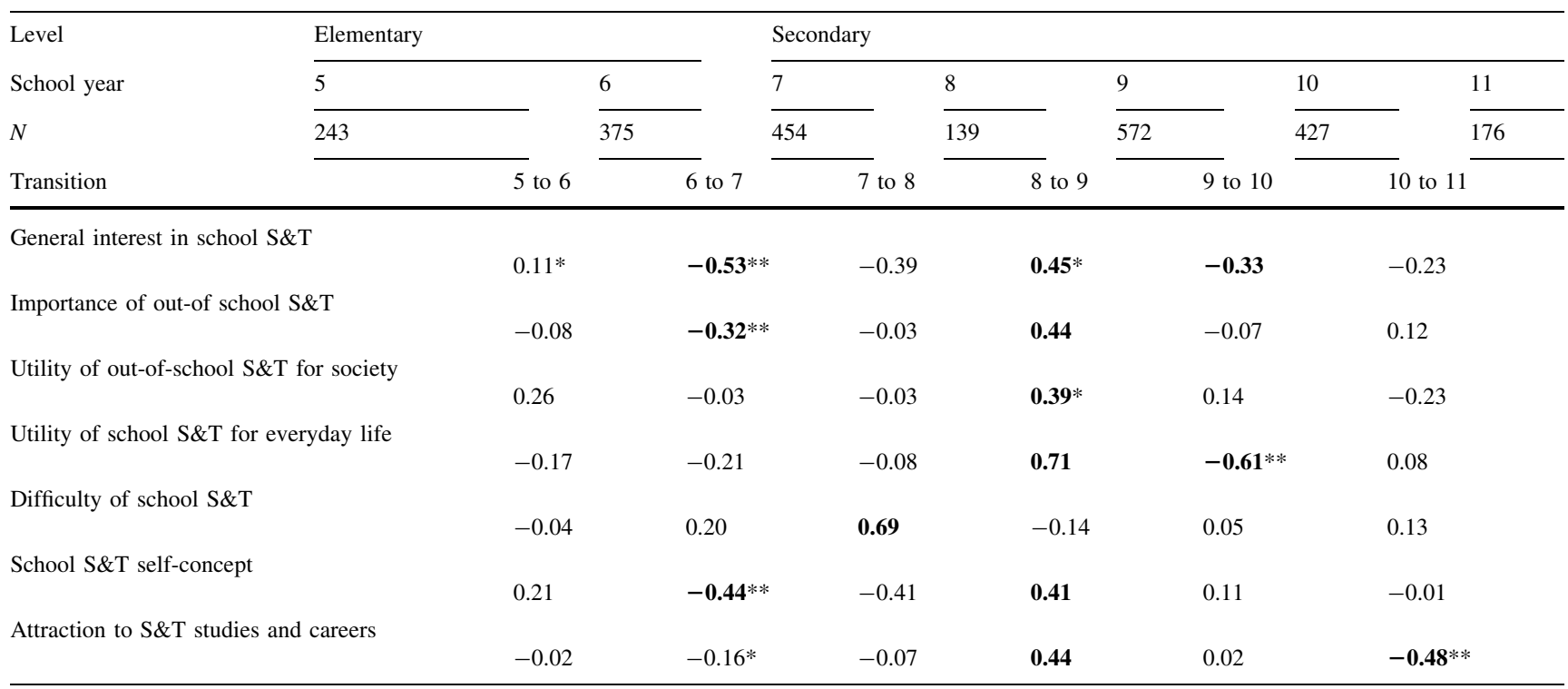

$* p \leq 0.05 ; * * \leq 0.005$ 
Fig. 1 Mean scores of actual S\&T teaching practices against school years

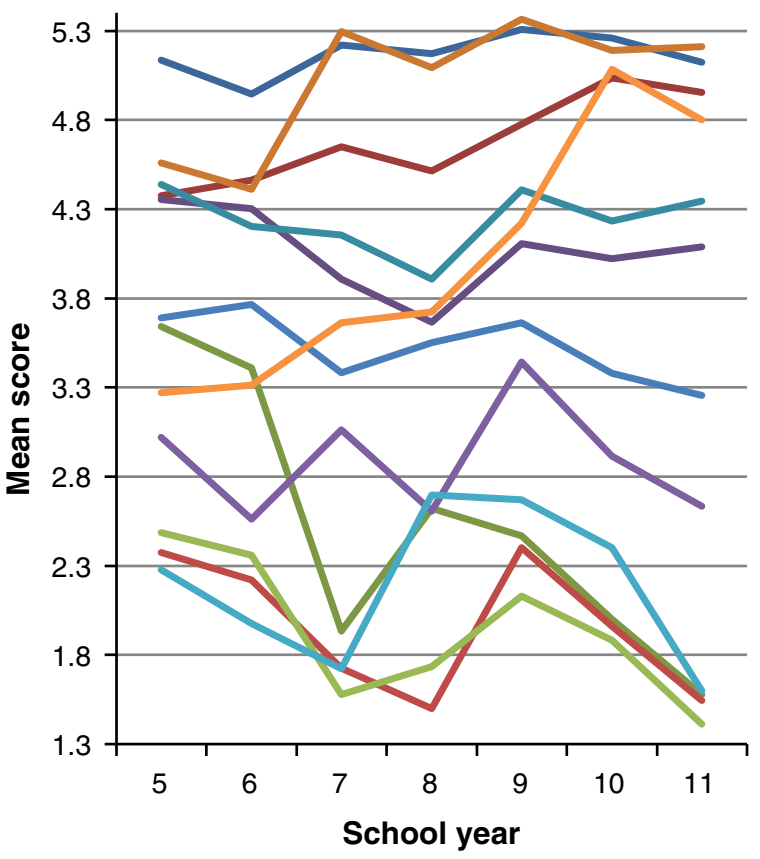

Teacher providing explanations before the class

Observations, manipulations, experiments

Oral presentations

Having discussions with other students and with the teacher

Consulting textbooks or websites

Worksheets, exercise books or booklets

Projects

Field trips (museums, parks, etc.)

Invited guests who talk about S\&T and careers

Documentary viewing

Participation to science fairs with help from the teacher

Mathematical calculations although not always significantly different. Clearly, something positive happens during grade 9. Generally speaking, this positive effect, although it does not ${ }^{8}$ make our indicators reach the best anterior scores, seems to be temporary except for "attraction to S\&T studies and careers" and for "School S\&T self-concept," which seem to survive through to grade 10 , but with "attraction to S\&T studies and careers", that surprisingly falls again at grade 11 , even though the regression for the entire period was positive (see Table 4). This increase could potentially be explained by something negative that happens in grade 8 and that would intensify the contrast with a possible positive experience in grade 9.

Another important observation is that the "out-ofschool" subconstructs appear to be undisturbed by the grade 9 bump, supporting (once again) their independence from the "in-school" subconstructs.

To further investigate the variations in the grade 6-7 and grade 8-9 transitions, we present exploratory supplementary analyses and thus Fig. 1, which presents year-to-year variations of frequencies of actual teaching practices.

Research Question No. 5b: What is the Evolution of Frequencies of Teaching Practices Over the Interval?

Table 7 shows the results of regressions for frequencies of actual teaching practices in S\&T. It is important to note that these regressions describe the general evolution of these practices with grade levels. Among the most striking

\footnotetext{
${ }^{8}$ Sorge (2007) had also noticed that "students do not recover their previously higher levels of science attitude in the later middle school years" (p.36).
}

Table 7 Results of the linear regression analysis for the frequency of actual teaching practices in S\&T

\begin{tabular}{|c|c|c|c|c|}
\hline & $N$ & Intercept & Slope & $p$ \\
\hline $\begin{array}{l}\text { Teacher providing } \\
\text { explanations before the } \\
\text { class }\end{array}$ & 1,271 & 5.066 & 0.039 & $0.003 * *$ \\
\hline $\begin{array}{l}\text { Observations, manipulation, } \\
\text { experiments }\end{array}$ & 1,267 & 4.365 & 0.114 & $<0.001 * *$ \\
\hline Oral presentations & 1,263 & 3.356 & -0.283 & $<0.001^{* *}$ \\
\hline $\begin{array}{l}\text { Having discussions with } \\
\text { other students and with } \\
\text { teacher }\end{array}$ & 1,263 & 4.216 & -0.043 & $0.020^{*}$ \\
\hline $\begin{array}{l}\text { Consulting textbooks and } \\
\text { websites }\end{array}$ & 1,263 & 4.246 & 0.007 & 0.738 \\
\hline $\begin{array}{l}\text { Worksheets, exercise } \\
\text { books, or booklets }\end{array}$ & 1,264 & 4.617 & 0.144 & $<0.001 * *$ \\
\hline Projects & 1,265 & 3.710 & -0.056 & $<0.001 * *$ \\
\hline $\begin{array}{l}\text { Field trips (museums, } \\
\text { parks, etc.) }\end{array}$ & 1,261 & 2.196 & -0.049 & $0.003 * *$ \\
\hline $\begin{array}{l}\text { Special guests who talk } \\
\text { about S\&T and careers }\end{array}$ & 1,267 & 2.287 & -0.101 & $<0.001 * *$ \\
\hline Viewing documentaries & 1,260 & 2.867 & 0.035 & $0.028^{*}$ \\
\hline $\begin{array}{l}\text { Participation in science } \\
\text { fairs with help from the } \\
\text { teacher }\end{array}$ & 1,259 & 2.057 & 0.054 & $0.004 * *$ \\
\hline Mathematical calculations & 1,265 & 3.040 & 0.334 & $<0.001 * *$ \\
\hline
\end{tabular}

$* p \leq 0.05 ; * * p \leq 0.005$

results for which we can suggest possible links with the decline of "in-school" subconstructs (see Table 4), it is worth noting that significant and the biggest $(>0.1)$ increases are seen in "observations, manipulations, and 
Table 8 Results of the linear regression analysis for the importance of other subjects over school S\&T

\begin{tabular}{lllll}
\hline & $N$ & Intercept & Slope & $p$ \\
\hline Arts & 1,242 & 2.719 & -0.123 & $<0.001^{* *}$ \\
$\begin{array}{l}\text { English (as a second } \\
\quad \text { language) }\end{array}$ & 1,241 & 4.454 & -0.16 & $<0.001^{* *}$ \\
French (as a first language) & 1,247 & 4.961 & -0.212 & $<0.001^{* *}$ \\
Mathematics & 1,243 & 5.043 & -0.196 & $<0.001^{* *}$ \\
Physical education & 1,240 & 3.737 & -0.261 & $<0.001^{* *}$ \\
Social Universe & 1,243 & 3.416 & -0.149 & $<0.001^{* *}$ \\
\hline
\end{tabular}

$* p \leq 0.05 ; * * p \leq 0.005$

experiments," "worksheets, exercise books, or booklets," and especially "mathematical calculations." Among these, the first two already had high $(>4)$ initial frequency scores. "Mathematical calculations," however, went from being rather uncommon (intercept at Y5 $=3.040$ ) to becoming very frequent (intercept at $\mathrm{Y} 11=5.044$ ).

"Oral presentation," and having "special guests" had significant and the biggest $(<-0.1)$ decreases. It is interesting to see that, from the students' point of view, they were already not very frequent at the elementary, especially for "guests" (intercept $=2.2$ ).

Among those for which the frequency changed very little, "teacher providing explanations before the class," "having discussions," "consulting textbooks and websites" were frequent practices, and "field trips" and "viewing documentaries," and "participation in science fairs with help from the teacher" were quite rare. As for "projects", its frequency remained undecided (3.7), but rather stable nonetheless.

Research Question No. 6: What Is the Evolution of Perceived Importance and of Perceived Difficulty Rankings of S\&T in Comparison to Other Disciplines?

Table 8 shows regressions for the importance of other subjects over school S\&T. It is interesting to note that all other relative importance shows negative slopes. This means that, compared to other school subjects one-by-one, $\mathrm{S} \& \mathrm{~T}$ increases the most in perceived importance.

Table 9 shows regressions for the perceived difficulty of other subjects over school S\&T. It is interesting to note that a majority of subjects have negative slopes. This means that, considering the available data, and compared with most school subject matters separately, S\&T has the biggest increase in perceived difficulty. Mathematics is the only subject that did not provide a significant result. The results for arts are not available due to an error in the questionnaire but there is no reason to think that it would have a slope considerably different than the others.
Table 9 Results of the linear regression analysis for the perceived difficulty of other subjects over school S\&T

\begin{tabular}{lllll}
\hline & $N$ & Intercept & Slope & $p$ \\
\hline Arts (not available) & NA & NA & NA & NA \\
English (as second & 1,282 & 0.804 & -0.346 & $<0.001^{* *}$ \\
$\quad$ language) & & & & \\
French (as first language) & 1,284 & 0.467 & -0.161 & $<0.001^{* *}$ \\
Mathematics & 1,208 & -0.012 & 0.004 & 0.883 \\
Physical education & 1,276 & -0.804 & -0.108 & $<0.001^{* *}$ \\
Social universe & 1,270 & 0.133 & -0.125 & $<0.001^{* *}$ \\
\hline
\end{tabular}

$* p \leq 0.05 ; * * p \leq 0.005$

\section{Discussion}

We believe that the first noteworthy result of the above presented analysis is a confirmation that our local reality (Province of Quebec_-greater Montreal area) does not differ from the general trend observed elsewhere. Indeed, the "interest for S\&T" construct scores decline from the 5 th grade to the 11th. It loses the equivalent of one entire point on our 6-level Likert-type scales. Therefore, as they grow older, children tend to appear less and less interested in S\&T (Table 2).

This sad result, taken alone, could lead to rather depressing conclusions like some of the ones presented in the context section. However, as it has been noticed in the past (Vedder-Weiss and Fortus 2011, p. 200), the decline of interest in school S\&T that we observed does not appear to be exclusive to school S\&T. Indeed, preference for S\&T does not especially suffer in comparison with other subject matters. In fact, other subjects usually considered as socially important such as Mathematics, French as a first language and also Physical education appear to have even more acute declines than S\&T. Indeed, their slopes or "relative preferences" (Table 3) show negative values. This suggests that it might be school itself that is not capable of holding on to the strong interest sometimes found at the elementary level, and not necessarily the specific properties of school S\&T. Kirikkaya et al. had already recorded that "liking school falls significantly at high grade levels" (2011, p. 376). Therefore, the problem of interest in school S\&T, and the assessment that is usually provided of it in the literature, might be difficult to distinguish from a more general loss of interest in school, and thus the problem we see in the "absolute measure" of the decline for S\&T might benefit from a reflection on how to interest children (or avoid disinterest) in school as a whole. We believe this result, even though not really positive, might act as some sort or a relief for $S \& T$ teachers who have been addressed sometimes very negative 
comments in the last years and pointed as a source of the problem of disinterest. We believe that it might be unfair that if more assessments and research on interest, motivation and attitude are conducted, it should necessarily lead to more blame.

When we turn to the analysis of the evolution of the major subconstructs of interest (Table 4), we find that it might not be too unfair to suggest confirmation (at least for our population) that, as children grow older, their interest in out-of-school S\&T increases, while their interest inschool S\&T declines considerably. Indeed, subconstructs closely associated with school degrade with age (including difficulty, if we consider an increase as negative), while subconstructs associated with out-of-school S\&T improve with age. Such a strong divergence suggests a rupture between the perceptions students have of $S \& T$ in society and what they experience in schools. It is possible that the positive image of S\&T conveyed in the media and in other social contexts improved the perceptions students hold of S\&T while they grow older, to the point that it survives schooling. Surprisingly, our data show that even attraction to S\&T studies and careers improved despite the declining perception of school S\&T. We believe these results to be in line with Maltese and Tai's interpretations, when they wrote:

Interestingly, many of the students planning to continue study in the science, technology, engineering, and math (STEM) fields reported on experiences that they did not enjoy in secondary school science. Students often reported being bored, not having a good sense of the career options in science fields, or simply enjoying other classes more. However, because of some vision of the career they wanted, or the flexibility that study in STEM would give them, these students planned to continue in science. The students who did not plan to continue in STEM reported similar educational experiences, but for this group, the experiences were strong enough to deter them from wanting to continue study of science and mathematics at an advanced level. (Maltese and Tai 2010, p. 671)

Our analysis suggests that the choice to pursue might be more closely linked to the perceptions of the importance and utility of out-of-school S\&T than to what is actually experienced in class. Who knows how much improving teaching practices might boost interest for "out-of school S\&T" or "attraction to S\&T studies or careers"?

While they follow their school path, students generally see S\&T as becoming more difficult and less gratifying (self-concept). We therefore believe that, since these subconstructs appear to be closely linked to interest, it could be recommended for the sake of interest that teachers multiply circumstances in which students will experience positive feedback in S\&T classes, and reduce the instances of negative experiences. We believe that this recommendation is in line with Hidi's model in which individual and autonomous interest is conditional to the repetition of triggered situational interests (Hidi and Renninger 2006). Finally, our data show not temporal evolution at all for "Utility of school S\&T for everyday life", and no detectable tendency. This result is difficult to interpret and rather puzzling in light of the usually considered fundamental function of S\&T that is to interpret reality. But the absence of tendency in this subconstruct could also be the result of the fact it refers to both in-school and out-of-school perception elements, which were recorded to diverge.

Our data also seem to confirm that boy-girl differences are rather small, although we did find it to be at a slight advantage for boys. In light of previous research, it appears clear that, to find differences, it would be best to look at interest in subdisciplines (e.g., biology vs. technology) or to concentrate "on smaller-than-discipline problems or contexts" (AUTHORS' 2014, p 13). The small difference might explain why previous studies have diverging results on the matter. We believe it is fair to suggest that a general difference of interest in school S\&T between boys and girls is not a major issue, but the smaller curricular choice could be.

When exploring the sorter variations of different subconstructs (Table 6), it is interesting to see that our data support the hypothesis according to which the transition from elementary to secondary is a difficult one. Indeed, half (four) of the recorded significant variations happened during the grades 6-7 transition, and they were all negative and most were rather important (Effect sizes $<-0.32$ ). The other significant variations were on the contrary spread in other transitions, and sometimes positive. However, we can note a concentration of these in the grades 8-9 transition, with also many variations with moderate and positive effect sizes. It therefore appears that this particular transition has many positive effects on Québec's students' interest. Another important significant, rather strong and negative short variation of "Utility of school science for everyday life" was also recorded in the transition from grades 9-10 and also another negative one for "Attraction to S\&T studies and careers". This last one is less difficult to interpret, though, because, at this point in their life, students have already chosen the next steps of their school path (different college programs submissions).

On an exploratory mode, we proposed, in Fig. 1, an analysis of the short variation of the frequencies students declare of certain teaching practices, which are typical of S\&T class action. A more thorough analysis of such variations will be presented in an upcoming publication. Here, we will limit ourselves to the examination of the most 
important short variations in practices that students experience in the grades 6-7 and 8-9 transitions in particular. For the elementary-secondary transitions, students perceive that they experience less of discussions, projects, oral presentations, invited guests and field trips. They also perceive a very important increase of "worksheets, exercise books and booklets", and smaller ones of "teacher providing oral explanations" and of "observations, manipulations and experiments". Since the majority of the recordings show a decrease, we can hypothesize that in this particular transition, the variety of teaching practices decreases, and concentrates on the three latter ones, especially on "worksheets, [...]". For the grades 8-9 transition, which is generally positive, we can see that a vast majority of measures increase (especially in field trips and documentary viewing), suggesting an improvement in the variety of teaching practices. Only "oral presentations" and "science fairs" appear to slightly decline. We believe that these results might suggest that a variety of approaches favour interest, but such hypotheses have to be prudent, since grade 9 is, in the province of Quebec, more concentrated on biology ("living universe"), and therefore it is possible that the study of this particular topic explains the positive effect. Indeed, general biology as well as human biology are clearly known as topics that interest adolescents. Grade 9 in Québec is also the opportunity for students to choose for the first time between two versions of the S\&T course, one more "fundamental" and the other more "applied", and therefore interest might partially be favoured by mere suitability. Nevertheless, the variety of teaching approaches is perceived as increasing in grade 9 and lowered at the entry of the secondary course.

Results from regressions (for the entire grades 5-11 timespan) of the same teaching practices presented in Table 7 offer an interesting perspective on the variations that have the potential to provide hypotheses about the general decline of interest for school S\&T. Among the most important variations on the entire period, we record slight increases of "observations, manipulations and experiments" and "worksheets, [...]"; a slight decrease of the presence in class of "special guests"; a rather important decrease in "oral presentations"; but mostly a very important increase in "mathematical calculations". It is unclear as the "causal" nature of these practices, but they nevertheless provide interesting hypotheses for further research. Also, "mathematic calculations" show the most striking increase in frequency with grade levels, but should not be surprising since advanced science gets increasingly interested in quantitative predictions. So, despite the fact that it goes along with the decline of interest, it is difficult to recommend rejecting (or maybe even reducing) calculations altogether.

Finally, when compared one-by-one with every other school subject (Tables 8 and 9), school S\&T has the greatest relative increase in perceived importance every time. Paradoxically, the same holds true for relative difficulty (though indistinguishably from mathematics), which suggest that Logan and Skamp's (2008) hypothesis according to which when difficulty rises, interest declines. It also appears that students value difficulty or feel that difficulty produces value (or both). S\&T is seen in school as increasingly difficult, but also increasingly valuable. While it may be tempting to suggest that school S\&T should be easier, students do not appear completely insensitive to challenge. It is not impossible that making S\&T less difficult could also cause a drop in S\&T's status.

\section{Conclusion}

In this research, we have attempted to answer questions related to the decline in interest in school science as students go through the school system. All of the provided analyses were produced in this perspective. We have verified that this widespread decline occurs in Québec and that interest declines in most "in-school" subconstructs yet increases in out-of-school subconstructs, and in attraction to S\&T studies and careers. Compared with other academic subjects, S\&T is seen as increasingly difficult and important and, based on preference scores, S\&T is not the onlynor the worse-school subject to decrease in popularity. These results suggest that there is something wrong with what happens in school and that, as Osborne (2003) might say, it would tragically appear that school has not done enough for students in terms of preserving their interest in science. We have shown that the difference between boys and girls in this matter is small and that, if we need to use boy-girl preferences to increase their respective interest, we should look further into more precise preferences. We have also found that in Quebec, interest tends to decline at the beginning of secondary school; however, we have also seen that it can be turned around at grade 9. We have proposed hypotheses for the steeper slopes that are linked to major changes in teaching practices and curricular differences.

We believe that this paper adds to the reflections in the field because it goes beyond absolute measures of interest/ motivation/attitude and the sometimes unfairly depressing conclusions that emerge from them. Of course the decline in school S\&T is unfortunate, but not exclusive to S\&T. Thus, some important solutions might also not be exclusive to S\&T. We also have seen that there appears to be a breach between perceptions of S\&T and perceptions of school. In light of the fundamental function of S\&T, which is to explain reality, an interesting approach might be to explore the-possibly structural-reasons why this rupture happened and appears to be maintained. The important 
structural differences in Québec' educational system between elementary and secondary courses, and at the entry at grade 9 , combined with the important variations of many components of interest during these short transitions suggest indeed that explanations might be structural.

Furthermore, the variety of deployed pedagogical means appears to be an important factor to address the interest challenge. The variations of the use of mathematic and of oral explanations in the teaching of S\&T also appear to be good candidates to better understand the evolution of interest. However, since they sometimes appear to be inevitable, the ways with which they are used can still be studied.

Some considerations can nonetheless limit the conclusions of the present research. First, even if there is no reason to believe that younger participants understood some of our questions in a radically different way from the older ones, there is no way to secure that they did not. In turn, it is not impossible that recorded declines or increases for certain components or items were linked to inclinations other that the ones we were interested in. However, since most our components were created with multiple items, we believe that the effect of eventual age-linked alternative understandings of their formulations might be softened. Also, the fact that some components or items decreased while some others increased is somehow reassuring. The interpretations derived from the use of the same items with different groups of participants is always subject to such risks but the regularity of their form can also be invoked to argue for robustness.

Another limit of our research is that it is a transversal one. Taking a picture of a cross-section of differently aged participants at a certain point in time does not secure that it shows progression, even though it can be argued as a rather fairly acceptable representation of such a progression. In the future, we will identify some particularly profiled students and retest them. Following the participants in a longitudinal study will thus allow suggestions of causalities. In the present case, our description can mostly serve to better frame further research and provide new research questions.

As we wrote at the beginning of this article, interest is not a futile affair. In fact, it can lead to better learning, which in turn contributes to society through democracy, domestic problem solving, consumption, and careers. Positive dispositions towards S\&T are also important so that S\&T can take its rightful place in society, making it accessible and desirable to everyone and not just to elite. We believe that it is possible to increase interest in the wonders of S\&T without letting the challenge that it represents lose its lustre. We contributed to this debate by providing rather convincing evidence based on an important number of subjects, on a large timespan and assessing a considerable number of aspects.

Acknowledgments Special thanks to the following school boards: Commissions scolaires de Montréal, Rivière-du-Nord, des HautesRivières, des Grandes-Seigneuries, Marie-Victorin, des Hauts-Cantons, des Sommets, de la Région-de-Sherbrooke, and des Patriotes for their financial and organizational help with this project. We would also like to thank Martin Riopel, François Thibault, Ousmane Sy, Jean-Philippe Bolduc, Marie-Hélène Bruyère, Amélia Darsigny, Cynthia Paré, Chloé Lemay-Dagenais, Guillaume Malenfant-Robichaud, Kamal Achachi, and Olivier Laforest for their precious help with the data input and analysis.

Open Access This article is distributed under the terms of the Creative Commons Attribution License which permits any use, distribution, and reproduction in any medium, provided the original author(s) and the source are credited.

\section{Appendix}

Questions considered for analysis. 


\begin{tabular}{|c|c|c|c|c|c|c|}
\hline $\begin{array}{l}\text { Compared to my friends, I } \\
\text { consider myself... }\end{array}$ & $\begin{array}{c}\text { Very weak at } \\
\text { school } \\
\square\end{array}$ & $\begin{array}{c}\text { Weak at school } \\
\square\end{array}$ & $\begin{array}{c}\text { Rather weak at } \\
\text { school } \\
\square\end{array}$ & $\begin{array}{l}\text { More or less } \\
\text { good at school } \\
\square\end{array}$ & $\begin{array}{c}\text { Good at school } \\
\square\end{array}$ & $\begin{array}{c}\text { Very good at } \\
\text { school } \\
\square\end{array}$ \\
\hline $\begin{array}{l}19 . \\
\text { Compared to other students, I } \\
\text { consider myself... }\end{array}$ & $\begin{array}{c}\text { Very weak in } \\
\text { S\&T } \\
\square\end{array}$ & $\begin{array}{c}\text { Weak in S\&T } \\
\square\end{array}$ & $\begin{array}{c}\text { Rather weak in } \\
\text { S\&T } \\
\square\end{array}$ & $\begin{array}{c}\text { Rather good in } \\
\text { S\&T } \\
\square\end{array}$ & $\begin{array}{c}\text { Good in S\&T } \\
\square\end{array}$ & $\begin{array}{c}\text { Very good in } \\
\text { S\&T } \\
\square\end{array}$ \\
\hline $\begin{array}{l}20 . \\
\text { Regarding my grades, I } \\
\text { consider myself... }\end{array}$ & $\begin{array}{c}\text { Very } \\
\text { unsatisfied } \\
\square\end{array}$ & $\begin{array}{c}\text { Unsatisfied } \\
\qquad \square\end{array}$ & $\begin{array}{c}\text { Rather } \\
\text { unsatisfied } \\
\square\end{array}$ & $\begin{array}{l}\text { Rather } \\
\text { satisfied } \\
\square\end{array}$ & $\begin{array}{c}\text { Satisfied } \\
\square\end{array}$ & $\begin{array}{c}\text { Strongly } \\
\text { satisfied } \\
\square\end{array}$ \\
\hline $\begin{array}{l}21 . \\
\text { Compared to my friends, I } \\
\text { understand S\&T... }\end{array}$ & $\begin{array}{c}\text { With much } \\
\text { difficulty } \\
\square\end{array}$ & $\begin{array}{c}\text { With difficulty } \\
\square\end{array}$ & $\begin{array}{l}\text { With more or } \\
\text { less difficulty } \\
\square\end{array}$ & $\begin{array}{l}\text { With more or } \\
\text { less ease } \\
\square\end{array}$ & $\begin{array}{c}\text { Easily } \\
\square\end{array}$ & $\begin{array}{c}\text { Very easily } \\
\qquad \square\end{array}$ \\
\hline $\begin{array}{l}22 . \\
\text { In S\&T, when I don't } \\
\text { understand, I always } \\
\text { eventually find ways. }\end{array}$ & $\begin{array}{c}\text { Strongly } \\
\text { disagree } \\
\square\end{array}$ & $\begin{array}{c}\text { Disagree } \\
\square\end{array}$ & $\begin{array}{c}\text { Somewhat } \\
\text { disagree } \\
\square\end{array}$ & $\begin{array}{c}\text { Somewhat } \\
\text { agree } \\
\square\end{array}$ & $\begin{array}{c}\text { Agree } \\
\square\end{array}$ & $\begin{array}{c}\text { Strongly agree } \\
\square\end{array}$ \\
\hline $\begin{array}{l}23 . \\
\text { In S\&T, when I don't } \\
\text { understand, I get easily } \\
\text { discouraged. }\end{array}$ & $\begin{array}{c}\text { Strongly } \\
\text { disagree } \\
\square\end{array}$ & $\begin{array}{c}\text { Disagree } \\
\square\end{array}$ & $\begin{array}{c}\text { Somewhat } \\
\text { disagree } \\
\square\end{array}$ & $\begin{array}{c}\text { Somewhat } \\
\text { agree } \\
\square\end{array}$ & $\begin{array}{l}\text { Agree } \\
\square\end{array}$ & $\begin{array}{c}\text { Strongly agree } \\
\square\end{array}$ \\
\hline
\end{tabular}

24.

For humans, S\&T...

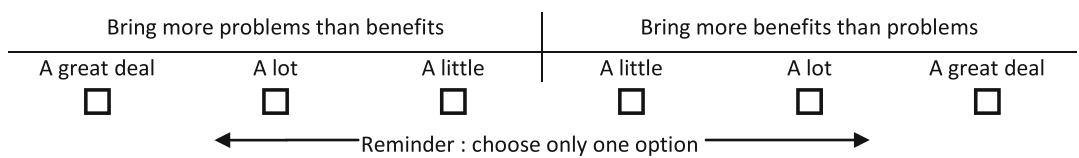

25.

S\&T...

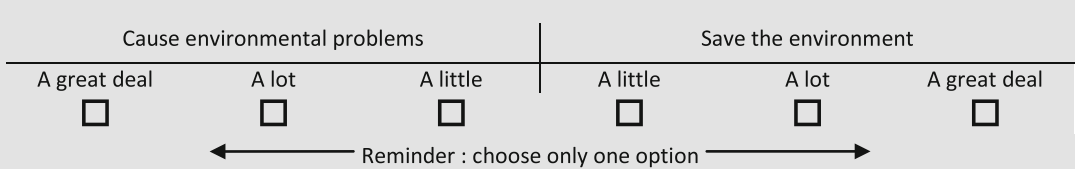

26.

S\&T...

\begin{tabular}{ccc|cc}
\multicolumn{3}{c|}{ Cause health problems } & \multicolumn{3}{c}{ Favour good health } \\
\hline A great deal & A lot & A little & A little & A great deal \\
\hline & $\square$ & $\square$ & $\square$
\end{tabular}

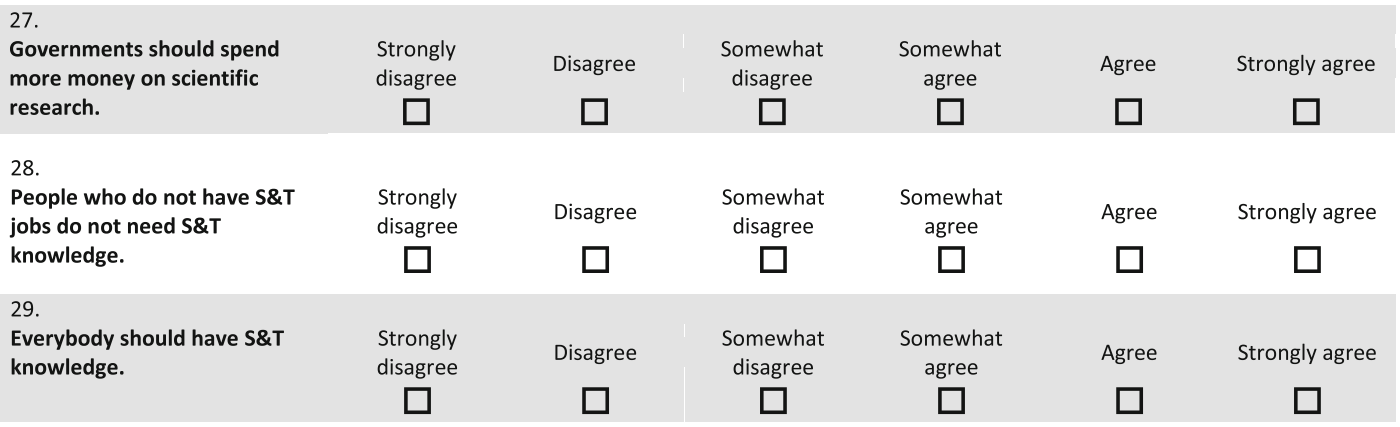

30.

S\&T...

\begin{tabular}{|c|c|c|c|c|c|}
\hline \multicolumn{3}{|c|}{ Are mostly useful to others } & \multicolumn{3}{|c|}{ Are mostly useful to me } \\
\hline $\begin{array}{c}\text { A great deal } \\
\square\end{array}$ & $\begin{array}{c}\text { A lot } \\
\square\end{array}$ & $\begin{array}{c}\text { A little } \\
\square\end{array}$ & $\begin{array}{c}\text { A little } \\
\square\end{array}$ & $\begin{array}{c}\text { A lot } \\
\square\end{array}$ & $\begin{array}{c}\text { A great deal } \\
\square\end{array}$ \\
\hline
\end{tabular}

\begin{tabular}{llc|cc} 
When I see scientific & \multicolumn{3}{c}{ It bores me } & \multicolumn{1}{c}{ It interests me } \\
\cline { 2 - 5 } $\begin{array}{l}\text { documentaries on television } \\
\text { or scientific information on } \\
\text { the web... }\end{array}$ & A great deal & A A lot & $\square$
\end{tabular}




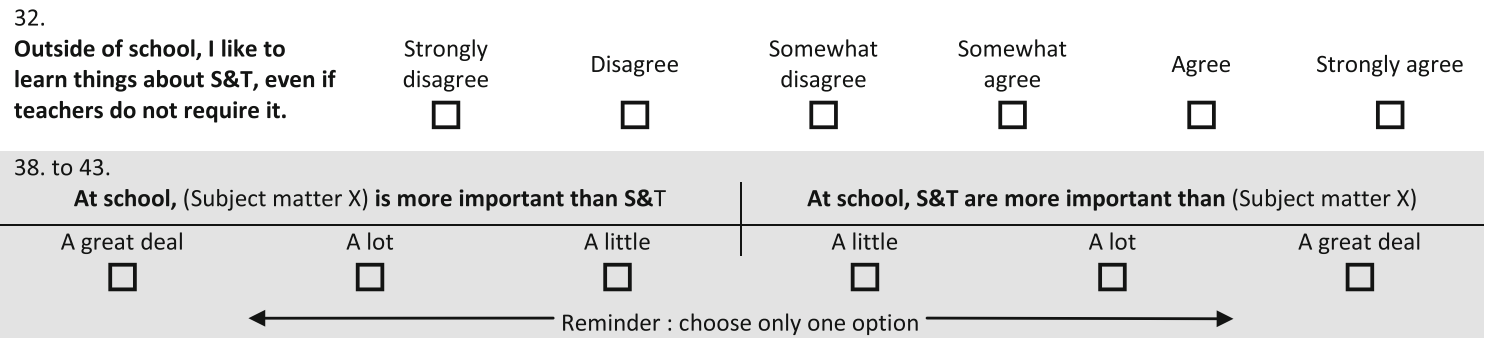

44. to 49.

\begin{tabular}{cc|c}
\multicolumn{2}{c}{ At school, I prefer (Subject matter X) rather than S\&T } & At school, I prefer S\&T rather than (Subject matter X) \\
\hline A great deal & A lot & Reminder : choose only one option
\end{tabular}

50. to 55.
For me, school (Subject matter
$\mathrm{X}$ ) is...

63. For me, solving S\&T $\quad$ Very hard
problems is....

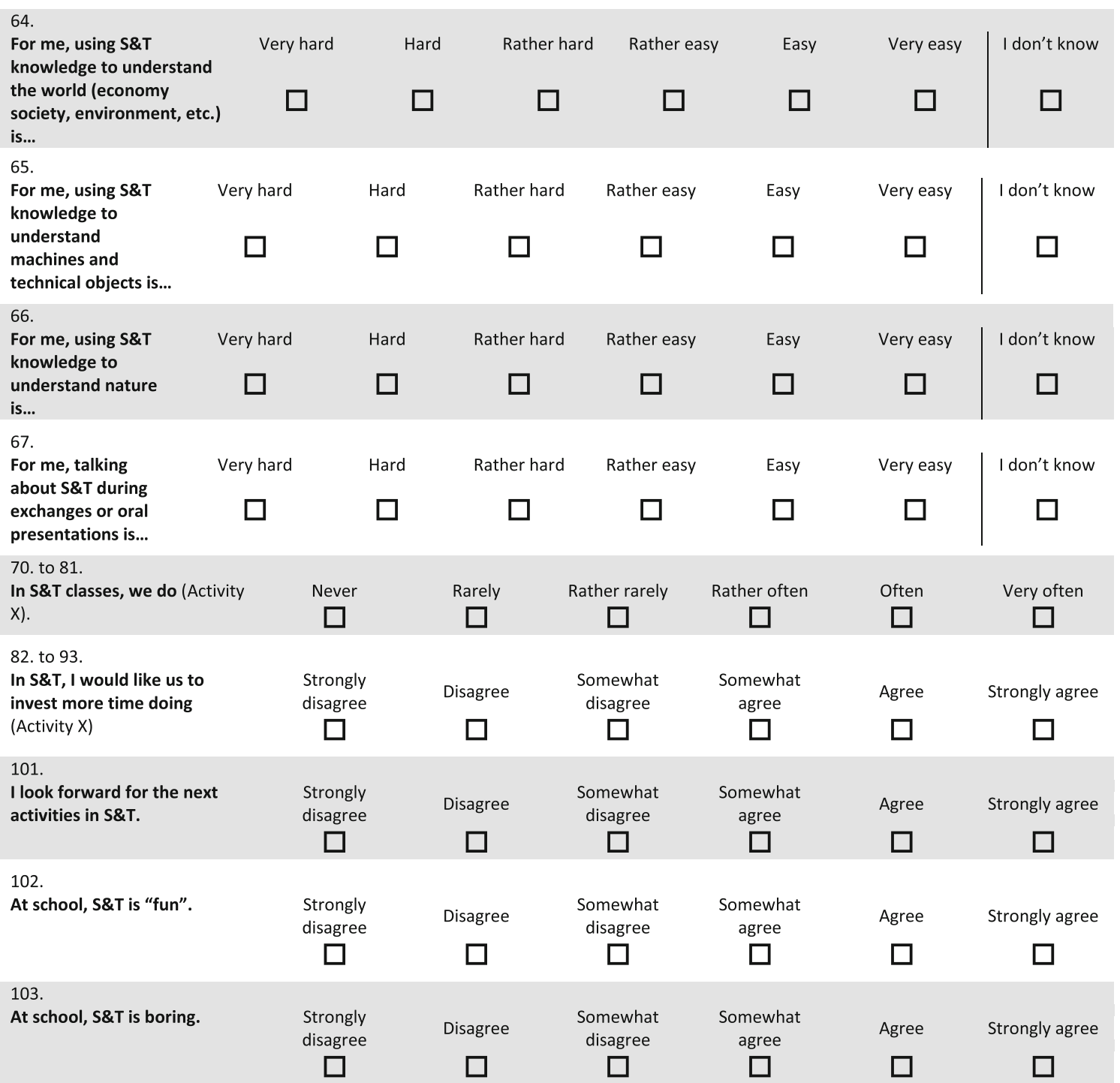


104.

$\begin{aligned} & \text { We should invest more time } \\ & \text { doing S\&T at school. }\end{aligned}$
$\begin{aligned} & \text { Strongly } \\ & \text { disagree }\end{aligned}$

111.

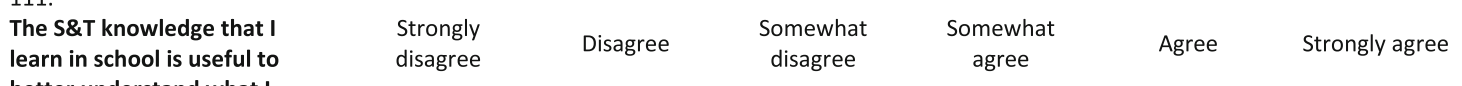

better understand what I

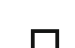

should do to protect the

environment.

\begin{tabular}{|c|c|c|c|c|c|c|}
\hline $\begin{array}{l}112 . \\
\text { The S\&T knowledge that I } \\
\text { learn in school is useful to } \\
\text { better understand what I } \\
\text { should do to manage my } \\
\text { sexuality. }\end{array}$ & $\begin{array}{l}\text { Strongly } \\
\text { disagree }\end{array}$ & Disagree & $\begin{array}{l}\text { Somewhat } \\
\text { disagree }\end{array}$ & $\begin{array}{l}\text { Somewhat } \\
\text { agree }\end{array}$ & Agree & $\square$ \\
\hline $\begin{array}{l}130 . \\
\text { I have the intention to learn } \\
\text { more about S\&T careers. }\end{array}$ & $\begin{array}{l}\text { Strongly } \\
\text { disagree } \\
\square\end{array}$ & $\begin{array}{c}\text { Disagree } \\
\square\end{array}$ & $\begin{array}{c}\text { Somewhat } \\
\text { disagree } \\
\square\end{array}$ & $\begin{array}{c}\text { Somewhat } \\
\text { agree } \\
\square\end{array}$ & $\begin{array}{c}\text { Agree } \\
\square\end{array}$ & $\begin{array}{c}\text { Strongly agree } \\
\square\end{array}$ \\
\hline $\begin{array}{l}131 . \\
\text { I do not want to know more } \\
\text { about S\&T careers. }\end{array}$ & $\begin{array}{l}\text { Strongly } \\
\text { disagree } \\
\square\end{array}$ & $\begin{array}{c}\text { Disagree } \\
\square\end{array}$ & $\begin{array}{c}\text { Somewhat } \\
\text { disagree } \\
\square\end{array}$ & $\begin{array}{c}\text { Somewhat } \\
\text { agree } \\
\square\end{array}$ & $\begin{array}{c}\text { Agree } \\
\square\end{array}$ & $\begin{array}{c}\text { Strongly agree } \\
\square\end{array}$ \\
\hline $\begin{array}{l}134 . \\
\text { I have the intention to pursue } \\
\text { S\&T studies. }\end{array}$ & $\begin{array}{l}\text { Strongly } \\
\text { disagree } \\
\square\end{array}$ & $\begin{array}{c}\text { Disagree } \\
\square\end{array}$ & $\begin{array}{c}\text { Somewhat } \\
\text { disagree } \\
\square\end{array}$ & $\begin{array}{c}\text { Somewhat } \\
\text { agree } \\
\square\end{array}$ & $\begin{array}{c}\text { Agree } \\
\square\end{array}$ & $\begin{array}{c}\text { Strongly agree } \\
\square\end{array}$ \\
\hline $\begin{array}{l}135 . \\
\text { It is out of the question that I } \\
\text { pursue S\&T studies. }\end{array}$ & $\begin{array}{l}\text { Strongly } \\
\text { disagree } \\
\square\end{array}$ & $\begin{array}{c}\text { Disagree } \\
\square\end{array}$ & $\begin{array}{c}\text { Somewhat } \\
\text { disagree } \\
\square\end{array}$ & $\begin{array}{c}\text { Somewhat } \\
\text { agree } \\
\square\end{array}$ & $\begin{array}{c}\text { Agree } \\
\square\end{array}$ & $\begin{array}{c}\text { Strongly agree } \\
\square\end{array}$ \\
\hline $\begin{array}{l}136 . \\
\text { I would like to practice a S\&T } \\
\text { career later. }\end{array}$ & $\begin{array}{l}\text { Strongly } \\
\text { disagree } \\
\square\end{array}$ & $\begin{array}{c}\text { Disagree } \\
\square\end{array}$ & $\begin{array}{c}\text { Somewhat } \\
\text { disagree } \\
\square\end{array}$ & $\begin{array}{c}\text { Somewhat } \\
\text { agree } \\
\square\end{array}$ & $\begin{array}{c}\text { Agree } \\
\square\end{array}$ & $\begin{array}{c}\text { Strongly agree } \\
\square\end{array}$ \\
\hline $\begin{array}{l}137 . \\
\text { It is out of the question that I } \\
\text { practice a S\&T career later. }\end{array}$ & $\begin{array}{l}\text { Strongly } \\
\text { disagree } \\
\square\end{array}$ & $\begin{array}{c}\text { Disagree } \\
\square\end{array}$ & $\begin{array}{c}\text { Somewhat } \\
\text { disagree } \\
\square\end{array}$ & $\begin{array}{c}\text { Somewhat } \\
\text { agree } \\
\square\end{array}$ & $\begin{array}{c}\text { Agree } \\
\square\end{array}$ & $\begin{array}{c}\text { Strongly agree } \\
\square\end{array}$ \\
\hline
\end{tabular}

\section{References}

Alexander JM, Jonhson KE, Kelley K (2012) Longitudinal analysis of the relations between opportunities to learn about Science and the development of interests related to science. Sci Educ 96(5):763-786. doi:10.1002/sce.21018

Barmby P, Kind PM, Jones K (2008) Examining changing Attitudes in secondary school science. Int J Sci Educ 30(8):1075-1093
Bennett J, Hogarth S (2009) Would you want to talk to a scientist at a party? High school students' attitudes to school science and to science. Int J Sci Educ 31(14):1975-1998

Cavas P (2011) Factors affecting the motivation of Turkish primary students for science learning. Sci Educ Int 22(1):31-42

Cheung D (2007) Students' attitudes toward chemistry lessons: the interaction effect between grade level and gender. Res Sci Educ 39(1):75-91 
Devetak I, Lorber ED, Jurisevic M, Glazar SA (2009) Comparing slovenian year 8 and year 9 elementary school pupils' knowledge of electrolyte chemistry and their intrinsic motivation. Chem Educ Res Pract 10(4):281-290

Francis LJ, Greer JE (2001) Shaping adolescents' attitudes towards science and religion in Northern Ireland: the role of scientism, creationism and denominational schools. Res Sci Technol Educ 19(1):39-53

George R (2006) A cross-domain analysis of change in students' attitudes toward science and attitudes about the utility of science. Int J Sci Educ 28(6):571-589

Gottfried AE, Marcoulides GA, Gottfried AW, Oliver PH (2009) A latent curve model of parental motivational practices and developmental decline in math and science academic intrinsic motivation. J Educ Psychol 101(3):729-739

Guvercin O, Tekkaya C, Sungur S (2010) A cross age study of elementary students' motivation towards science learning. Hacettepe Univ J Educ 39:233-243

Hassan G (2008) Attitudes toward science among Australian tertiary and secondary school students. Res Sci Technol Educ 26(2):129-147

Hidi S, Renninger KA (2006) The four-phase model of interest development. Educ Psychol 41(2):111-127

Hong Z-R, Lin H-S (2011) An investigation of students' personality traits and attitudes toward science. Int J Sci Educ 33(7): $1001-1028$

Kirikkaya EB (2011) Grade 4 to 8 primary school students' attitudes towards science: science enthusiasm. Educ Res Rev 6(4): 374-382

Krapp A, Prenzel M (2011) Research on interest in science: theories, methods, and findings. Int J Sci Educ 33(1):27-50

Logan M, Skamp K (2008) Engaging students in science across the primary secondary interface: listening to the students' voice. Research in science education (38)

Maltese AV, Tai RH (2010) eyeballs in the fridge: sources of early interest in science. Int J Sci Educ 32(5):669-685

Murphy C, Ambusaidi A, Beggs J (2006) Middle east meets west: comparing children's attitudes to school science. Int J Sci Educ 28(4):405-422
Osborne J, Simon S, Collins S (2003) Attitudes towards science: a review of the literature and its implications. Int J Sci Educ 25(9): 1049-1079

Owen S, Dickson D, Stanisstreet M, Boyes E (2008) Teaching physics: students' attitudes towards different learning activities. Res Sci Technol Educ 26(2):113-128

Pan Y, Gauvain M (2012) The continuity of college students' autonomous learning motivation and its predictors: a three-year longitudinal study. Learn Indiv Differ 22(1):92-99

Pell T, Jarvis T (2001) Developing attitude to science scales for use with children of ages from five to eleven years. Int J Sci Educ 23(8):847-862

Pell T, Jarvis T (2010) Developing attitude to science scales for use with children of ages from five to eleven years. Int J Sci Educ Technol 23(8):847-862. doi:10.1080/09500690010016111

Potvin P, Hasni A (2014) Interest, motivation and attitude towards science and technology at K-12 levels: a systematic review of 12 years of educational research. Stud Sci Educ 50(1):85-129. doi: $10.1080 / 03057267.2014 .881626$

Reid N, Skryabina EA (2002) Attitudes towards physics. Res Sci Technol Educ 20(1):67-81

Singh K, Granville M, Dika S (2002) Mathematics and science achievement: effects of motivation, interest, and academic engagement. J Educ Res 95(6):323-332

Sorge C (2007) What happens? Relationship of age and gender with science attitudes from elementary to middle school. Sci Educ 16(2):33-37

Turner S, Ireson G (2014) Fifteen pupils' positive approach to primary school science: when does it decline? Educ Stud 36(2):119-141. doi:10.1080/03055690903148662

Vedder-Weiss D, Fortus D (2011) Adolescents' declining motivation to learn science: inevitable or not? J Res Sci Teach 48(2):199-216

Venturini P (2004) Note de synthèse: attitudes des élèves nevers les sciences: le point des recherches. Revue française de pédagogie 149:97-121 